\title{
Development and validation of an RP-HPLC method for estimation of cefuroxime axetil and its degradation products in tablets
}

\begin{abstract}
A simple precise specific sensitive and accurate stability indicating RP-HPLC method for determination of cefuroxime Axetil and its degradation products in tablets. The separation was performed on Teknokroma, tracer excel C 8 column $(15 \mathrm{~cm} \mathrm{x} 0.46 \mathrm{~cm} .5 \mu \mathrm{m})$ using mobile phase consisting of $0.02 \mathrm{M}$ potassium dihydrogen phosphate: methanol: Acetonitrile $(60: 35: 5 \mathrm{v} / \mathrm{v})$. The flow rate was $1 \mathrm{~mL} / \mathrm{min}$ and detection was monitored at $278 \mathrm{~nm}$. The column temperature was set at $35^{\circ} \mathrm{C}$. The retention times were $2.4,11.09$, $12.6,12.6,14.13,20.76$ and 24.24 minutes for cefuroxime Axetil B, cefuroximeA A, $\Delta^{\wedge} 3$-isomers, E-isomer 1 and E-isomer 2, respectively. The calibration curves were found to be linear in the concentration range of $120-312 \mu \mathrm{g} / \mathrm{mL}(\mathrm{r} 2=0.99964)$ and $0.24-7.2 \mu \mathrm{g} / \mathrm{mL}(\mathrm{r} 2=0.9997)$ at assay level and low-level of cefuroxime Axetil. The percentage recoveries of cefuroxime Axetil at assay level were found to be in the range of $98.54-99.35 \%$ and $101.4-103.69 \%$ at low-level at $95 \%$ confidence limit. The intraday precision was $0.517 \%$ and $2.019 \%$ at to assay level and low-level of CFA, respectively. The intermediate precisions were $1.102 \%$ and $2.273 \%$ at assay level and low-level of CFA, respectively.
\end{abstract}

Volume 4 Issue 5 - 2016

\author{
Ahmed Gad kariem,' Ali Ahmed Algaradi,' Ali \\ Gamal Ahmed Al-Kaf, ${ }^{2}$ Talal Alssmani ${ }^{3}$ \\ 'Department of pharmaceutical chemistry, Khartoum University, \\ Sudan \\ ${ }^{2}$ Department of medicinal and analytical chemistry-faculty of \\ pharmacy, Sana'a University, Yemen \\ ${ }^{3}$ Department of pharmaceutical chemistry \& faculty of \\ pharmacy, Omdurman Islamic University, Sudan
}

\begin{abstract}
Correspondence: Ali Ahmed Algaradi, Department of pharmaceutical chemistry, Khartoum University, Sudan, Tel 009677। 1705756, Email alialgaradi2012@gmail.com
\end{abstract}

Received: March 01, 2016 | Published:September 02, 2016

\section{Introduction}

Cefuroxime Axetil (CFA) is a mixture of the 2diastereoisomers of (1RS)-1-(acetyloxy) ethyl (6R,7R)-3-[(carbamoyloxy)methyl]-7[[(Z)-2-(furan-2-yl)-2-(methoxyimino)acetyl]amino]-8-oxo-5-thial-

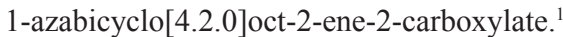

Cefuroxime Axetil is the orally absorbed ester prodrug of the cefuroxime sodium. Since cefuroxime sodium is not absorbed orally, the 1-acetyloxyethyl ether was substituted for sodium on the cefuroxime molecule to increase its lipid solubility and improve its gastrointestinal absorption. ${ }^{2}$

The absorbed ester is hydrolyzed in the intestinal mucosa and in portal circulation. ${ }^{3}$ Estimation of cefuroxime Axetil has been described by spectrophotometry, ${ }^{3-5}$ HPTLC $^{6-8}$ and HPLC. ${ }^{-18}$ HPLC methods are available in United State Pharmacopoeia ${ }^{19}$ and in British pharmacopoeia. ${ }^{1}$ The column in the official methods is Trimethylsilane bonded-phase. The mobile phase consisting of $0.2 \mathrm{M}$ ammonium dihyrogen phosphate $(23 \mathrm{gm} / \mathrm{litre})$. In the official methods the buffer concentration is very high and that may be lead to adversely affect on the operation of HPLC system. The buffer may be precipitate in the column and LC system when it is exposed to the highest organic concentration. The backpressure is very high.

The column in the B.P and USP methods is trimethylsilane which is less stable than longer-chain alkyl bonded phase packing (e.g., $\mathrm{C}_{8}$ and $\mathrm{C}_{18}$ ). The proposed method was carried out on $\mathrm{C}_{8}$ column which more stable than $\mathrm{C} 1$ column and the operation backpressure was very low because the buffer concentration was low $\left(0.02 \mathrm{M} \mathrm{KH}_{2} \mathrm{PO}_{4}\right)$.

\section{Experimental}

\section{Instrumentation}

An HPLC system from Shimadzu Corporation consisting of an
LC-20 AT pump, SPD-20 A UV/vis-detector, (CT-20A oven, DGU $20 \mathrm{~A} 3$, a rheodyne injector with $20 \mu \mathrm{L}$ loop, teknokroma, tracer excel. $\mathrm{C}_{8}$ analytical column $(15 \mathrm{cmx} 0.46 \mathrm{~cm}, \mu \mathrm{m})$ and $\mathrm{C}_{1}$ column $(25 \mathrm{~cm} \mathrm{x}$ $0.46 \mathrm{~cm}, 5 \mu \mathrm{m})$

\section{Reference substances, reagents and chemicals}

Cefuroxime Axetil was obtained from archid chemical (India), methylparaben, sodium benzoate was obtained from shiba pharma (Yemen). Monobasic ammonium potassium phosphate was obtained from fluka (Switzerland). Methanol HPL grade, acetonitrile HPL grade and tetrahydrofuran HPLC grade were obtained from sigmaaldrich (Germany). Water was obtained from arium-sartorius water purified system (Germany).

\section{Mobile phase preparation}

Mobile phase was prepared by mixing, $0.02 \mathrm{M}$ potassium dihydrogen phosphate, methanol and acetonitrile in the ratio of 60:35:5.

\section{Chromatographic conditions}

Column: Teknokroma,

$\mathrm{C} 8(150 \mathrm{~mm} \times 4.6 \mathrm{~mm} \times 5 \mu \mathrm{m})$ column temperature: $35^{\circ} \mathrm{C}$

Flow rate: $1 \mathrm{~mL} /$ minute

Wavelength: $278 \mathrm{~nm}$

Injection volume: $20 \mu \mathrm{L}$

Run time: 25minutes

\section{Standard preparation}

Standard stock solution of cefuroxime Axetil was prepared by dissolving 30mg of CFA in methanol to get a concentration of $1.2 \mathrm{mg}$ / 
$\mathrm{mL}$. Ten $\mathrm{mL}$ of this solution was transferred to a $50 \mathrm{~mL}$ volumetric flask and diluted with mobile phase.

\section{Sample preparation}

Twenty tablets were weighed. An accurately amount of the finely powdered tablet equivalent to $120 \mathrm{mg}$ of cefuroxime Axetil was taken and transferred into a $100 \mathrm{~mL}$ volumetric flask fifty a $\mathrm{mL}$ of methanol was added, shaked by mechanical means for about 10 minuts and diluted with methanol to volume. The resultant solution was filtered through $0.45 \mu \mathrm{m}$ syring filter. The first $10 \mathrm{~mL}$ was discarded and $10 \mathrm{~mL}$ of filtrate was transferred into a $50 \mathrm{~mL}$ volumetric flask, diluted with mobile phase to the mark and twenty $\mu \mathrm{L}$ was injected. A portion of the standard solution was exposed to sunlight for 5 hours to generate E-isomers. A portion of the standard was heated for 1 hour or more at $60{ }^{\circ} \mathrm{C}$ temperature to generate the $\Delta^{\wedge} 3$-isomers.

\section{Related substances}

Using the procedure described under assay. The percentage area content of related substances were calculated from the areas of the peaks in the chromatogram was obtained with test solution by normalization procedure. The sum of the areas of the pair of peaks in the chromatogram obtained with test solution corresponding to the E-isomers is not greater than $1.5 \%$ by normalization, the sum of the areas of any peaks corresponding to $\Delta^{\wedge} 3$-isomers is not greater than $2.0 \%$ by normalization. The area of any other secondary peak is not greater than $1.0 \%$ by normalization. ${ }^{1}$ The relative retention times are about 0.8 for CFA- diastereisomer B, 0.9 for CFA A, and 1.0 for CFA delta-3-isomer; the resolution, $\mathrm{R} s$, between the CFA diastereisomer $\mathrm{A}$ and $\mathrm{B}$ peaks is not less than 1.5 and the resolution $\mathrm{R} \_\mathrm{s}$, between the cefuroxime Axetil diastereisomer A and the cefuroxime axetil delta3 -isomers is not less than 1.5. The column efficiency is not less than 3000 theoretical plates when measured using the CFA A peak and the $\%$ RSD is not more than $2.0 \%$

\section{Determination linearity for assay of CFA}

Different aliquots of standard stock solution $(1.2 \mathrm{mg} / \mathrm{mL})$ were transferred into a series of volumetric flasks and diluted to the mark with mobile phase to obtain final concentrations of $120 \mu \mathrm{g} / \mathrm{mL}, 168 \mu \mathrm{g} /$ $\mathrm{mL}, 204 \mu \mathrm{g} / \mathrm{mL}, 240,276 \mu \mathrm{g} / \mathrm{mL}$ and $312 \mu \mathrm{g} / \mathrm{mL}$. Twenty $\mu \mathrm{L}$ of each of CFA (standard solution) was injected in triplicate.

\section{Determination of linearity at low-level of CFA for de-} gradation products

Different aliquots of standard solutions $(0.24 \mathrm{mg} / \mathrm{mL})$ were transferred into a series of volumetric flasks and diluted to the mark with mobile phase to obtain final concentration of $0.24 \mu \mathrm{g} / \mathrm{mL}, 1.2 \mu \mathrm{g} /$ $\mathrm{mL}, 2.4 \mu \mathrm{g} / \mathrm{mL}, 3.6 \mu \mathrm{g} / \mathrm{mL}, 4.8 \mu \mathrm{g} / \mathrm{mL}$ and $7.2 \mu \mathrm{g} / \mathrm{mL}$. Twenty $\mu \mathrm{L}$ of each CFA standard solution was injected, in triplicate.

Determination of accuracy for assay of cefuroxime Axetil (accuracy was performed on $250 \mathrm{mg}$ CFA tablet)

Accurate weight of CFA ( $21 \mathrm{mg}, 30 \mathrm{mg}$ and $35 \mathrm{mg}$ ) were introduced into three volumetric flask $(25 \mathrm{~mL})$ and $(61 \mathrm{mg})$ of placebo for CFA was added to each volumetric flask, dissolved and completed to volume with methanol (Stock solution). A aliquot $(10 \mathrm{~mL})$ of each stock solution was transferred into different $(50 \mathrm{~mL})$ volumetric flask and diluted with mobile phase to obtain concentrations of $168 \mu \mathrm{g} / \mathrm{mL}$, $240 \mu \mathrm{g} / \mathrm{mL}$ and $312 \mu \mathrm{g} / \mathrm{mL}$. The final solution was filtered through syring filter $(0.45 \mu \mathrm{m})$ and twenty $\mu \mathrm{L}$ was injected.

Three replicate were prepared for each level. The percent recovery was determined by an external standard at $100 \%$ level.

\section{Determination of accuracy at low-level of CFA for de- termination of degradation products}

Different aliquots from standard solutions $(0.24 \mathrm{mg})$ were transferred and mixed with $61 \mathrm{mg}$ of placebo into a series of volumetric flasks. The volumes were completed with mobile phase to obtain concentrations of $0.24 \mu \mathrm{g} / \mathrm{mL}, 1.2 \mu \mathrm{g} / \mathrm{mL}, 2.4 \mu \mathrm{g} / \mathrm{mL}, 3.6 \mu \mathrm{g} / \mathrm{mL}$, $4.8 \mu \mathrm{g} / \mathrm{mL}$ and $7.2 \mu \mathrm{g} / \mathrm{mL}$. Three replicate were prepared for each level .The final solution were twenty $\mu \mathrm{L}$ was injected. The percent recovery was determined by an external standard at $100 \%$ level $(0.24 \mathrm{mg} / \mathrm{mL})$.

\section{Precision}

Determination of repeatability precision for assay of CFA: Spiked placebo solution was prepared by transferring $120 \mathrm{mg}$ of CFA and $61 \mathrm{mg}$ of placebo into a $100 \mathrm{~mL}$ and diluted to the mark with methanol. Ten $\mathrm{mL}$ of spiked placebo solution was transferred into $50 \mathrm{~mL}$ V.F and diluted with mobile phase to the mark. Solution was filtered through syring filter $(0.45 \mathrm{mg})$ and twenty $\mu \mathrm{L}$ was injected. Six replicate sample solutions was prepared and two injection of each sample were injected.

Determination of intermediate precision for assay: Intermediate precision was performed such as repeatability procedure on different days and different preparations.

Determination of repeatability precision for degradation products at low- level of CFA: Spiked placebo solution was prepared by transferring $120 \mathrm{mg}$ of CFA into a $100 \mathrm{~mL}$ volumetric flask and diluted to the mark with methanol. Ten $\mathrm{mL}$ of this solution was transferred into a $50 \mathrm{~mL}$ and diluted with mobile phase to the mark. Two $\mathrm{mL}$ of second solution $(0.24 \mathrm{mg} / \mathrm{mL})$ and $61 \mathrm{mg}$ of placebo were transferred into a $100 \mathrm{~mL}$ volumetric flask and diluted with mobile phase to the mark. Twenty $\mu \mathrm{L}$ was injected. Six replicate samples were prepared and two injection of each sample were injected.

Determination of intermediate precision at low-level: Intermediate precision was performed such as repeatability procedure on different day and different preparations.

\section{Determination of limit of detection (LOD) and limit of quantitation (LOQ)}

Different aliquots of standard solution $(0.024 \mathrm{mg} / \mathrm{mL})$ were transferred into a series volumetric flask and diluted with mobile phase to obtain concentrations of $0.0048 \mu \mathrm{g} / \mathrm{mL}, 0.012 \mu \mathrm{g} / \mathrm{mL}, 0.024 \mu \mathrm{g} / \mathrm{mL}$, $0.12 \mu \mathrm{g} / \mathrm{mL}$ and $1.2 \mu \mathrm{g} / \mathrm{mL}$. Twenty $\mu \mathrm{L}$ was injected.

\section{Forced degradation studies}

Acid degradation: A $10 \mathrm{~mL}$ aliquot of stock standard solution and $10 \mathrm{~mL}$ of sample spiked placebo solution were pipetted into two $50 \mathrm{~mL}$ volumetric flask and $5 \mathrm{~mL}$ of $0.1 \mathrm{~N} \mathrm{HCl}$ was added to each volumetric flask. The two solutions were stored for 28 hours in room temperature and then neutralized with $5 \mathrm{~mL}$ of $0.1 \mathrm{~N} \mathrm{NaOH}$. The solutions were diluted with mobile phase to the volume and twenty $\mu \mathrm{L}$ was injected.

Base degradation: A $10 \mathrm{~mL}$ of the CFA stock solution and a $10 \mathrm{~mL}$ of sample (spiked placebo) solution were transferred into two $50 \mathrm{~mL}$ volumetric flask and $5 \mathrm{~mL}$ of $0.1 \mathrm{~N} \mathrm{NaOH}$ was added to each flask. 
The solution were stored in room temperature for twohours in room temperature and then neutralized with $5 \mathrm{~mL}$ of $0.1 \mathrm{~N} \mathrm{HCl}$. The solutions were diluted with mobile phase to volume and twenty $\mu \mathrm{L}$ was injected.

\section{Hydrogen peroxide degradation}

A $10 \mathrm{~mL}$ of the CFA stock solution $(1.2 \mathrm{mg} / \mathrm{mL})$ and a $10 \mathrm{~mL}$ of sample $(1.2 \mathrm{mg} / \mathrm{mL})$ were transferred into two $50 \mathrm{~mL}$ volumetric flask and $5 \mathrm{~mL}$ of $3 \%$ hydrogen peroxide was added to each flask. The solution were stored in room temperature for 24 hours and then diluted with mobile phase to the mark and twenty $\mu \mathrm{L}$ was injected.

\section{Light degradation}

A $10 \mathrm{~mL}$ of the CFA stock solution $(1.2 \mathrm{mg} / \mathrm{mL})$ and a $10 \mathrm{~mL}$ of the sample stock solution $(1.2 \mathrm{mg} / \mathrm{mL})$ were transferred into two $50 \mathrm{~mL}$ volumetric flask. The two solutions were exposed to sunlight for 5 hours and then diluted with mobile phase to the mark and twenty $\mu \mathrm{L}$ was injected.

\section{Heat degradation}

A $10 \mathrm{~mL}$ of the CFA stock solution $(1.2 \mathrm{mg} / \mathrm{mL})$ and a $10 \mathrm{~mL}$ of the sample solution were transferred into two $50 \mathrm{~mL}$ volumetric flask. The two solutions were heated at $90^{\circ} \mathrm{C}$ for 2 hours then diluted into the mark with mobile phase and twenty $\mu \mathrm{L}$ was injected.

i. Determination of robustness for assay

ii. An assay standard solution was prepared as according in the analytical method.

iii. Acetonitrile (5\%) was varied by $\pm 10 \%$

iv. Methanol (35\%) was varied by $\pm 10 \%$

v. The flow rate $1 \mathrm{~mL} / \mathrm{min}$ was varied by $\pm 10 \%$

vi. The column temperature $\left(35^{\circ} \mathrm{C}\right)$ was varied by $\pm 5 \%$

vii. The system suitability standard solution was injected twice

\section{Determination solution stability}

Fresh standard and spiked placebo were prepared and analyzed as per the test method. Time zero value for each were established. An aliquot of each solution was placed in clear glassware and exposed to ambient (benchtop) conditions and aliquot was place of in a refrigerator. The solutions were analyzed every 24 hours for at least 2 days (48hr) and two injections was injected of each solution.

\section{Results and discussion}

Several mobile phases were tried in different ratios. For $80 \% \mathrm{v} / \mathrm{v}$ methanol, the retention time was 1.8 mintes and the peak was near t0, distorted and no peaks were observed after 20 minutes-Since, successive reduction in $\%$ methanol by $20 \% \mathrm{v} / \mathrm{v}$ was required and a weaker mobile phase was increased. For $60 \%$ methanol, the retention time was 2.8 min and the peaks CFAB/CFAA were overlapped. For $40 \%$ $\mathrm{v} / \mathrm{v}$ methanol, the retention times were 1.81, 9.64, 11.08, 12.58, 18.09 and 21.57 minutes for cefuroxime (CF), CFAB, CFAA, $\Delta^{\wedge} 3$-isomers, E-isomer1 and E-isomer2,respectively. There was good separation but methylparaben was overlapped with CFAB. The retention times of CFAB and CFAA were no effected by $\mathrm{pH} 2.5,3.5$ because they were neutral. The retention time of cefuroxime was increased at $\mathrm{pH} 2.5$ because the cefuroxime is acidic compound $\left(\mathrm{Pk}_{\mathrm{a}} 2.5\right)$. Therefore the decrease in $\mathrm{pH}$ leads to increase the hydrophobicity of $\mathrm{CF}$ which lead to increase the retention time in RP-HPLC.

Since, change in organic solvent from methanol to acetonitrile was required by using the solvent-monograph to an estimate the required value of $\% \mathrm{ACN},(33.3 \% \mathrm{ACN})$, that give similar run time as for $40 \%$ methanol. For $33.33 \% \mathrm{ACN}$, the retention time was 10.78 and 11.81 for CFAB and CFAA and the resolution between CFAB/CFAA was 2.0 the retention time was 7.33 for methylparaben. When $33.3 \%$ $\mathrm{ACN}$ in water was used, the peaks of methylparaben and CFAB were resolved, but the resolution between CFAB and CFAA was decreased. Since, mixtures of $\mathrm{ACN}$ and methanol were tried by blending equal volume of the $40 \%$ methanol and $33.3 \% \mathrm{ACN}$.

Different ratios of methanol: Acetonitrile: phosphate buffer were tried (23.4:16.6:60),(32:8:60) and (35:5:60) . Different temperatures were tried at $30^{\circ} \mathrm{C}, 35^{\circ} \mathrm{C}$ and $40^{\circ} \mathrm{C}$.

The best mobile phase was 0.02M KH2PO4: ACN: $\mathrm{Me} O \mathrm{OH}$ methanol in ratio $(60: 5 \%: 35 \%)$ which showed good and complete separation of cefuroxime Axtile and its degradation products. The run time for cefuroxime Axetil and its degradation products was 35 minutes in USP method while. In the present work, the run time was 25 minutes as shown in Figure 1. Forced degradation studies were performed to demonstrate specificity of stability-indicating method. The stress test solution were performed by exposing the standard and spiked placebo solution to acidic, basic, peroxide, light and warmth conditions. The chromatograms of the stress tests were shown that, there were no interference between the degradation products and peaks of the CFA. The loss of CFA content was a corresponding to increase in the level of decomposition products as shown in Table 1.

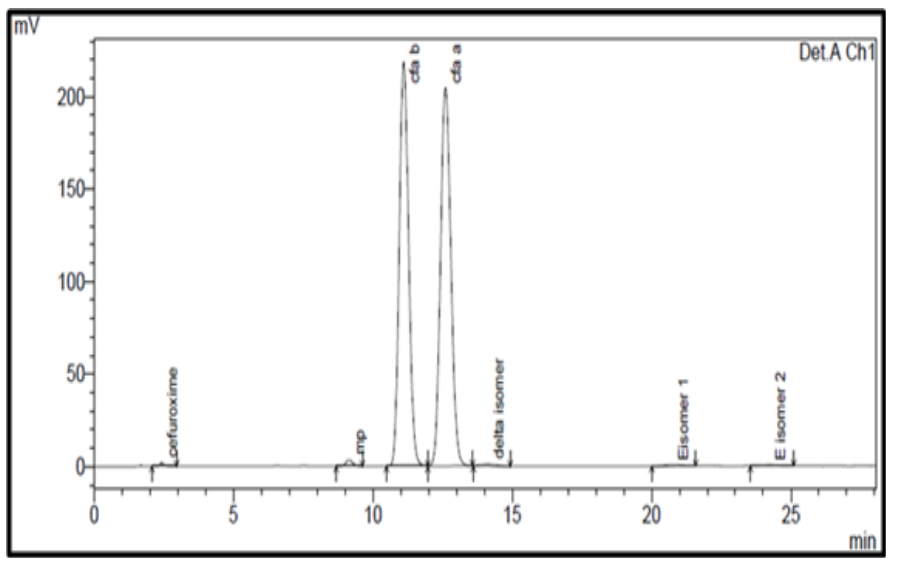

Figure I Separation of CFA and its degradation products.

The CFA was disappeared of in basic condition this indicates that there were not co eluent in the position of CFA peaks. The unaffected assay of CFA in the presence of decomposition products confirms the stability-indicating power of the method.

\section{Robustness}

The concept of robustness of an analytical procedure has been defined by $\mathrm{ICH}^{20}$ as a measure of its capacity to remain unaffected by small, but deliberate variation in method parameters. The method parameters were varied according to Table 2 and the figures of merit were measured. The results in Table 3 showed that acceptable resolution, N, tailing factor, \%RSD and R.T for CFAA were obtained. All system suitability requirements were met except that 
R.T was obtained of $10 \%$ methanol variation was outside the system suitability requirement ( \pm 2 minutes). The method was robustness. The system suitability tests are used to verify that the resolution and reproducibility of the HPLC system and analysis procedure are adequate for the analysis, the results obtained were shown in Table 2 \& Table 3

Table I Results obtained by the proposed RP-HPLC for determination CFA and its degradation products

\begin{tabular}{|c|c|c|c|}
\hline \multicolumn{2}{|l|}{ Item } & $\begin{array}{l}\text { CFA at assay } \\
\text { level }\end{array}$ & CFA at low-level \\
\hline \multicolumn{2}{|c|}{ Retention time } & 11.9 & 11.9 \\
\hline \multicolumn{2}{|c|}{ Wavelength of detection (nm) } & 278 & 278 \\
\hline \multicolumn{2}{|c|}{ Range of linearity $(\mu \mathrm{g} / \mathrm{mL})$} & $|20-3| 2$ & $0.24-7.2$ \\
\hline \multicolumn{2}{|c|}{ Calibration point } & 6 & 6 \\
\hline \multicolumn{2}{|c|}{ Regression equation } & $\begin{array}{l}Y=44221 x \\
+48106\end{array}$ & $Y=44773 x+22002$ \\
\hline \multicolumn{2}{|c|}{ Regression coefficient(r2) } & 0.999619 & 0.999974 \\
\hline \multicolumn{2}{|l|}{ SDa } & 48021 & 55.63 \\
\hline \multicolumn{2}{|l|}{ SDb } & 209 & 221.5 \\
\hline \multicolumn{2}{|c|}{$\begin{array}{l}95 \% \text { Confidence limit of the } \\
\text { slope }\end{array}$} & $43777-44665$ & 44655-4489 I \\
\hline \multicolumn{2}{|c|}{$\begin{array}{l}95 \% \text { Confidence limit of the } \\
\text { intercept }\end{array}$} & -1503602 & -939.1 \\
\hline \multicolumn{2}{|c|}{ Standard error of the estimation } & 57318 & 546.1 \\
\hline \multicolumn{2}{|c|}{$\operatorname{LOD}(\mu \mathrm{g} / \mathrm{mL})$} & 3.58 & $0.004 I$ \\
\hline \multicolumn{2}{|c|}{$\mathrm{LOQ}(\mu \mathrm{g} / \mathrm{mL})$} & 10.9 & 0.00124 \\
\hline \multicolumn{2}{|c|}{ Intraday \%RSD } & 0.517 & 2.019 \\
\hline \multicolumn{2}{|c|}{ Interday \%RSD } & 1.102 & 2.273 \\
\hline \multirow[t]{2}{*}{ \%Recovery } & \%mean & 98.95 & 102.55 \\
\hline & $\begin{array}{l}95 \% \text { Confidence } \\
\text { limit of mean }\end{array}$ & $98.54-99.35$ & $101.4-103.69$ \\
\hline
\end{tabular}

Table 2 System suitability test for the proposed RP-HPLC method for the determination of cefuroxime axetil

\begin{tabular}{ll}
\hline $\begin{array}{l}\text { System suitability } \\
\text { parameters }\end{array}$ & Cefuroxime axetil-A \\
\hline $\mathrm{N} \geq 2000$ & 7189 \\
$\mathrm{~T} \leq 2$ & 1.19 \\
$\mathrm{R} \geq 1.5$ Resolution between CFA & 2.155 \\
and $\Delta 3$-isomer & 7.2 \\
$\mathrm{k} \geq 2$ & 0.17 \\
\%RSD $\leq 2.0 \%$ & $11.96 \mathrm{I}$ \\
R.T & \\
\hline
\end{tabular}

Stability of solution sample and standard solution which were stored at room temperature for 48 hours were not stable because ; \% difference from initial time point was $2.92 \%$ and $3 \%$ for standard and sample solutions respectively. The acceptance criteria for stability of solution for assay is not more than $2 \%$ from initial point time, while, the sample and standard solutions which were stored in refrigerator for 48hours were stable.

Since, assay preparation promptly, or refrigerate and use on the day prepared. The intraday precisions were $0.51 \%$ and $2.019 \%$ at assay and low level, respectively. The inter day precisions were $1.102 \%$ and low-level, respectively as show in Table 3.

The results for the evaluation the linearity of cefuroxime Axetil at assay level were given in Table 4. The correlation coefficient of 0.99962 which was acceptable -the slope was 44221 and the Y-intercept was 48106. The regression equation for the graph was computed and found to be: $y=44221 x+48106 \rightarrow(1)$, where $x$ is concentration in $\mu \mathrm{g} / \mathrm{mL}$ the regression statistics was performed by Excel and SPSS. The Y-intercept was $0.45 \%$ compared to the calculated Y-value at $100 \%$ standard $(240 \mu \mathrm{g} / \mathrm{mL})$ and the acceptance criteria was $\leq 2.0 \%$. The residual standard deviation was $0.53 \%$ (standard error compared to calculate Y-value at $100 \%$ level) and an acceptance criterion was $\leq 2.0 \%$. These results clearly demonstrate a linear relationship between the peak areas and the concentrations of CFA in the ranges of $120 \mu \mathrm{g} /$ $\mathrm{mL}$ to $312 \mu \mathrm{g} / \mathrm{mL}$.

The results for the evaluation of the linearity of CFA at low-level were given in Table 4 . In the ranges of $0.24 \mu \mathrm{g} / \mathrm{mL}$ to $7.2 \mu \mathrm{g} / \mathrm{mL}$ shown that the correlation coefficient was 0.9999 and which was acceptable .The slope was 44773 and intercept was 22.02 the regression equation for the graph was computed and found to be: $y=44773 x+22.02 \rightarrow(2)$, where $\mathrm{x}$ is the concentration at low-level. The regression statistics were performed by Excel and SPSS. Y-intercept value was $0.02 \%$ and acceptance criteria of $\leq 5 \%$ based on $1 \%$ level $(2.4 \mu \mathrm{g} / \mathrm{mL})$. The residual standard deviation was $0.51 \%$ and the acceptance criterion of $10 \%$.

The results clearly demonstrate a linearity relationship between the peak areas and the concentrations of the range of $0.24 \mu \mathrm{g} / \mathrm{mL}$ to $7.2 \mu \mathrm{g} /$ $\mathrm{mL}$. The difference in slope of upper range and slope of lower range in linearity curves was $1.25 \%$ and the acceptance criterion of $\leq 4.0 \% .^{21}$ Therefore, the $100 \%$ standard or area percent normalization could be used to quantitate the levels of degradation products. The results in Table 4 shown that the percent recovery for assay of CFA was inside of $100 \pm 2 \%$ limit for the average of each level. Each individual sample recovery was inside of $98-102 \%$ limit. The recovery of the RP-HPLC method for the assay of CFA was demonstrated by a mean of $98.95 \%$.

The results in Table 4 shown that, the recovery of the individual and average of each degradants level was within the range of $75 \%$ - $125 \%$ at each concentration level. The LOD was $0.0024 \mu \mathrm{g} / \mathrm{mL}$ $(0.002 \%)$ and the LOQ was $0.2 \mu \mathrm{g} / \mathrm{mL}(0.01 \%)$. Statistical comparison between the results was obtained by the proposed RP-HPLC and the official HPLC reference method (USP30) for assay of CFA tablet. The calculated value of $t$ was 2.34 which was less than the tabulated t value of 2.78 with 4 degrees of freedom (df) at the $5 \%$ level, the difference was not significant at $5 \%$ level between the two methods, concerning accuracy and precision as shown in Table 5. Comparison between the results of determination of the degradants of CFA tablet was obtained by the proposed RP-HPLC method and the official HPLC reference method. ${ }^{1}$ The British pharmacopoeia (2010) has published a monograph for tablets in which the sum of the areas of the pair of peaks corresponding to the E-isomers is not greater than $1.5 \%$ 
by normalization, the sum of the areas of $\Delta^{\wedge} 3$-isomers is not greater than $2 \%$ by normalization and the area of any other secondary peak is not greater than $1.0 \%$ by normalization.
The result in Table 6 \& Figure 3 that, the levels of cefuroxime, unknown $1, \Delta^{\wedge} 3$-isomers and E-isomers did not more than $1 \%, 2 \%$ and $1.5 \%$ respectively which were in acceptable level in both methods .

Table 3 Robustnes of proposed RP-HPLC method for assay of cefuroxime axetil

\begin{tabular}{|c|c|c|c|c|c|c|}
\hline \multirow[t]{2}{*}{ Method conditions } & & 11.098 & 5400 & 1.093 & 4 & 1.9 \\
\hline & $1.1 \mathrm{~mL} / \mathrm{min}$ & 10.23 & 5485 & 1.087 & 5.82 & 1.87 \\
\hline \multicolumn{7}{|l|}{ Flow rate } \\
\hline & $30^{\circ} \mathrm{C}$ & 12.77 & 5797 & 1.085 & 7.85 & 1.924 \\
\hline \multicolumn{7}{|l|}{ Columns Temperature } \\
\hline & $40^{\circ} \mathrm{C}$ & 10.743 & 6112 & 1.093 & 5.83 & 2 \\
\hline & - $10 \%$ Methanol & 15.02 & 7236 & 1.12 & 9 & 2.089 \\
\hline & $+10 \%$ Methanol & 7.87 & 5361 & I.II & 4.24 & 1.63 \\
\hline
\end{tabular}

Table 4 Results of forced degradation for cefuroxime axetil

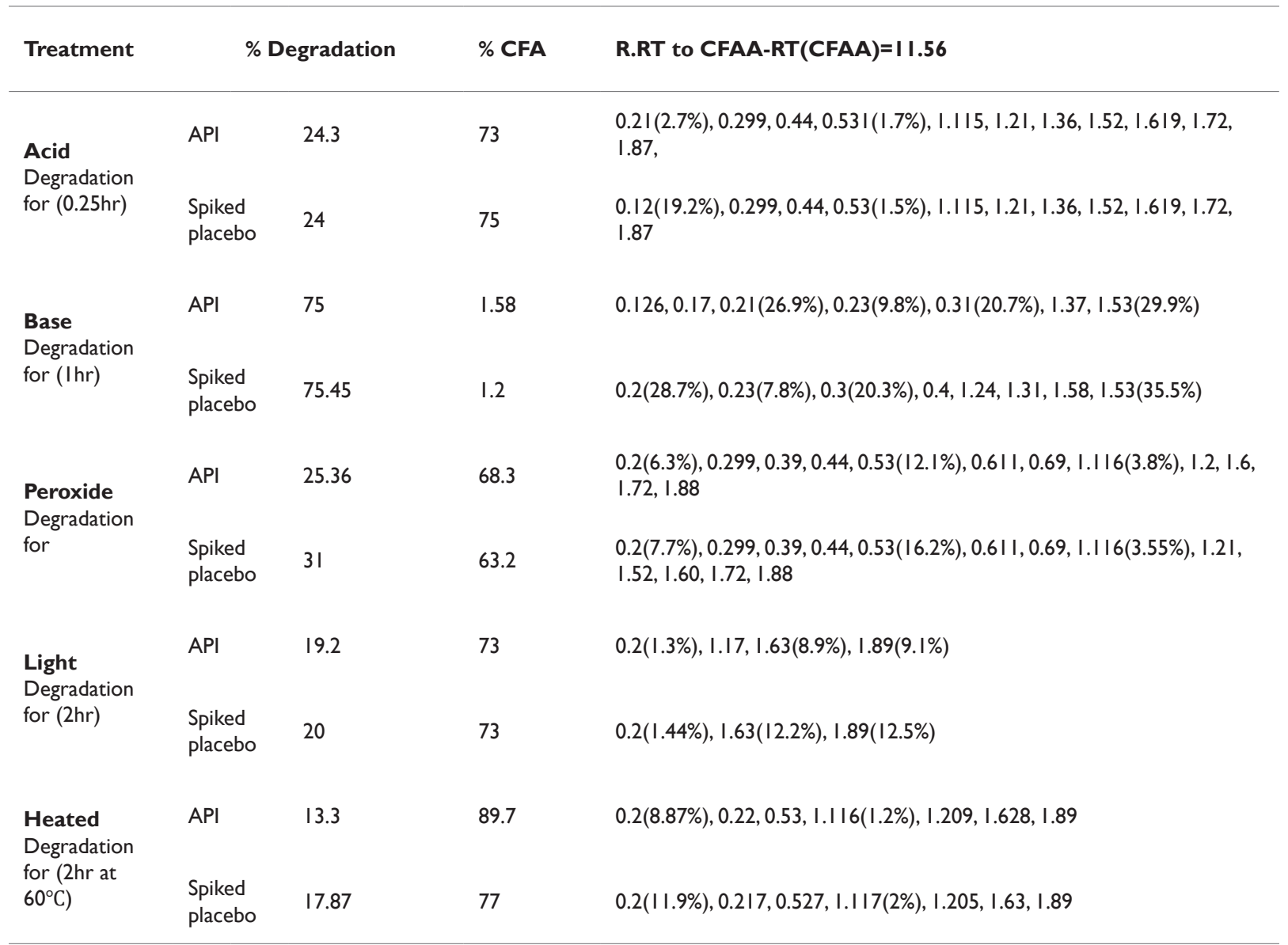




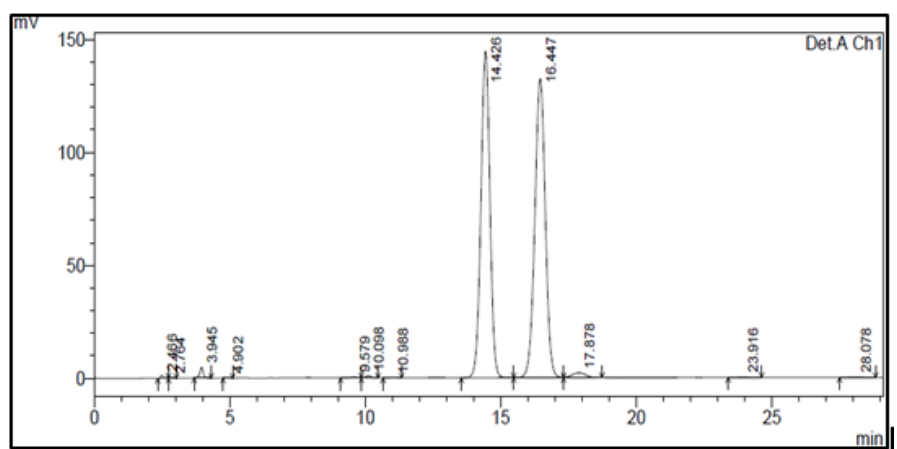

Figure $\mathbf{2}$ Chromatogram of degradation products CFA sample analyzed by USP and B.P method.

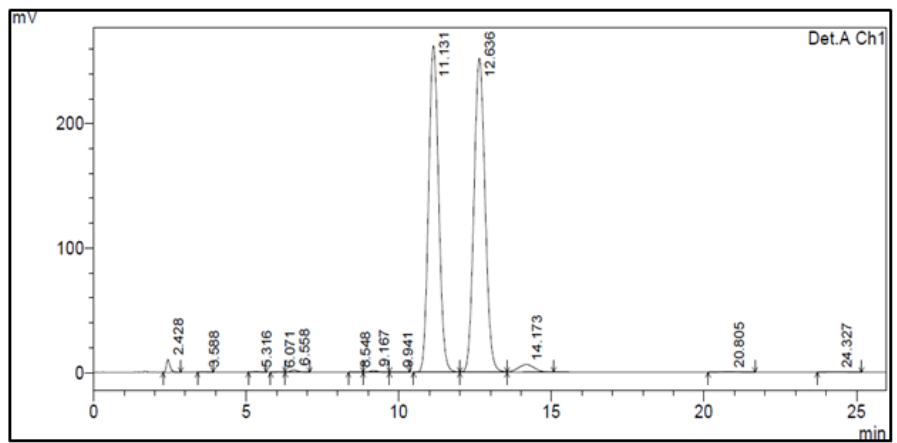

Figure 3 Chromatogram of degradation products CFA sample analyzed by the proposed method.

Table 5 Significance test for proposed-RP-HPLC method for the assay of cefuroxime axetil tablets compared with reference method

\begin{tabular}{|c|c|c|}
\hline $\begin{array}{l}\text { Statistical } \\
\text { term }\end{array}$ & $\begin{array}{l}\text { Reference } \\
\text { method (USP)2 }\end{array}$ & $\begin{array}{l}\text { Proposed RP-HPLC } \\
\text { method } 2\end{array}$ \\
\hline & 100.0818 & 99.1935 \\
\hline & 99.5883 & 99.07506 \\
\hline & 99.62778 & 99.04545 \\
\hline & 98.7987 & 98.7 \\
\hline & 99.63765 & 99.0948 \\
\hline Mean & 99.546846 & 99.02176 \\
\hline S.D \pm & 0.4643308 & 0.188256 \\
\hline \%RSD & 0.4664445 & 0.190116 \\
\hline$n$ & & \\
\hline $\mathrm{F}$ test $(6.38)$ & 6.083562 & \\
\hline $\begin{array}{l}\text { Calculated } \\
\mathrm{t}(2.78)\end{array}$ & 2.343362 & \\
\hline
\end{tabular}

Table 6 Test for significance for the proposed RP-HPLC method for degradation products of cefuroxime axetil tablet compared with reference method (B.P)

\begin{tabular}{|c|c|c|c|c|}
\hline \multirow{2}{*}{ Name } & \multicolumn{2}{|c|}{ Reference method } & \multicolumn{2}{|c|}{ Proposed method } \\
\hline & RRT & $\%$ & RRT & $\%$ \\
\hline \multirow{5}{*}{ Cefuroxime } & 0.23 & 0.459 & & 0.653 \\
\hline & & 0.517 & & 0.676 \\
\hline & & 0.561 & & 0.708 \\
\hline & & 0.607 & & 0.723 \\
\hline & & 0.66 & & 0.743 \\
\hline$x^{-}$ & & 0.5608 & & 0.7006 \\
\hline SD & & 0.077873 & & 0.036143 \\
\hline \%RSD & & 13.88605 & & $5.15883 \mid$ \\
\hline$F$ test $(6.388)$ & \multicolumn{2}{|c|}{4.642272} & & \\
\hline $\mathrm{t}(2.446)$ & \multicolumn{2}{|c|}{3.641193} & & \\
\hline \multirow{4}{*}{ Unknown I } & 0.58 & 0.107 & 0.52 & 0.269 \\
\hline & & 0.126 & 0.52 & 0.252 \\
\hline & & 0.092 & & 0.269 \\
\hline & & 0.108 & & 0.259 \\
\hline$x^{-}$ & & 0.10825 & & 0.26225 \\
\hline SD & & 0.013913 & & 0.008302 \\
\hline$\%$ RSD & & 12.85305 & & $3.16553 \mid$ \\
\hline$F$ test $(9.276)$ & \multicolumn{2}{|c|}{2.808948} & & \\
\hline \multirow[t]{3}{*}{$\mathrm{t}(2.57)$} & \multicolumn{2}{|c|}{19.01017} & & \\
\hline & 1.09 & 0.834 & 1.12 & 1.09 \\
\hline & & 0.905 & & 1.208 \\
\hline \multirow[t]{3}{*}{$\Delta^{\wedge} 3$-isomer } & & 0.966 & & 1.252 \\
\hline & & 1.03 & & 1.33 \\
\hline & & 1.05 & & 1.34 \\
\hline$x^{-}$ & & 0.957 & & 1.244 \\
\hline SD & & 0.089292 & & 0.102088 \\
\hline \%RSD & & 9.330372 & & 8.206447 \\
\hline $\mathrm{F}$ test $(0.156)$ & \multicolumn{2}{|c|}{0.765016} & & \\
\hline \multirow[t]{3}{*}{$\mathrm{t}(2.306)$} & \multicolumn{2}{|c|}{4.731698} & & \\
\hline & 1.45 & 0.113 & 1.65 & 0.136 \\
\hline & & 0.116 & & 0.137 \\
\hline \multirow[t]{3}{*}{ E-isomer I } & & 0.118 & & 0.137 \\
\hline & & 0.119 & & 0.138 \\
\hline & & 0.112 & & 0.141 \\
\hline$x^{-}$ & & 0.1156 & & 0.1378 \\
\hline SD & & 0.00305 & & 0.001924 \\
\hline \%RSD & & 2.638054 & & I.39589| \\
\hline$F$ test(6.388) & \multicolumn{2}{|c|}{2.513514} & & \\
\hline \multirow[t]{3}{*}{ t 2.36) } & \multicolumn{2}{|c|}{13.76786} & & \\
\hline & 1.71 & 0.096 & & 0.118 \\
\hline & & 0.097 & & 0.122 \\
\hline \multirow[t]{3}{*}{ E-isomer 2} & & 0.01 & & 0.123 \\
\hline & & 0.101 & & 0.121 \\
\hline & & 0.106 & & 0.124 \\
\hline$x^{-}$ & & 0.082 & & 0.1216 \\
\hline SD & & $0.04044 I$ & & 0.002302 \\
\hline \%RSD & & 49.31868 & & 1.893234 \\
\hline$F$ test $(6.388)$ & \multicolumn{2}{|c|}{308.5849} & & \\
\hline$t(2.776)$ & \multicolumn{2}{|c|}{2.186011} & & \\
\hline
\end{tabular}


Statistical comparison between degradants results obtained by two methods shown that, the difference between the content of all degradants product contents were significant difference. The $\%$ level of the all degradants obtained by new method were more than the $\%$ level of degradants, obtained by official method that may be due to the new method was more sensitive or more extracted than the official method. The method has been validated for the assay and determination of degradants of CFA in tablets. The method was shown to be selective, precise, linear and accurate within the range of $50 \%$ to $15 \%$ of target concentration $100 \%$ level and within the range of $0.05 \%$ to $3 \%$ of the target concentration at low-level. The method was shown to be robust with methanol volume established as critical parameter. The standard and sample solution was shown to be stable for 48 hour under refrigerated condition.

\section{Conclusion}

The proposed method was found to be linear at assay level of CFA in the range of $120 \mu / \mathrm{mL}$ to $312 \mu / \mathrm{mL}$ and linear at low-level of CFA UN the range of $0.24-7.2 \mu / \mathrm{mL}$. The proposed method was found to be precise, intermediate precise and accurate at assay level of CFA and at low-level of CFA. All degradation products formed during forced degradation studies were well separated from the CFA, demonstrating that the developed method was specific and stability-indicating. The method was shown to be robust with methanol volume established as critical parameter. The $100 \%$ standard solution or area percent normalization could be used to quantitate the levels of degradation products of CFA. The statistical test between results was obtained by proposed method for determination of CFA at assay level compared to reference method was not significant difference. The test ascertained that the new method was as the reference method. The $\%$ levels of the all degradants obtained by the proposed method were more than the reference methods, which may be due to the new method, were more sensitive or more extracted than the official methods.

The proposed method was found to be simple sensitive, specific, rapid and economic for determination of CFA and its degradation products in tablets. The LOD and LOQ were found to be $0.0024 \mu \mathrm{g} / \mathrm{mL}$ $0.024 \mu \mathrm{g} / \mathrm{mL}$, respectively. The standard and sample solution were not stable for 48 hours at room temperature, since solutions of CFA must be promptly used or stored in refrigerator and use on the day prepared. The RP-HPLC method for determination of CFA and its degradation products can be used for stability studies for CFA in tablets. The RP-HPLC method for CFA and its degradants is suitable for routine analysis and quality control of pharmaceutical dosage form.

\section{Acknowledgements}

None.

\section{Conflict of interest}

Author declares that there is no conflict of interest.

\section{References}

1. B.P. British Pharmacopoeia. Published on the Recommendation of the Commission. 2010;3:2476,3026.

2. Powell DA, James NC, Ossi MJ, et al. Pharmacokinetics of Cefuroxime Axetil Suuspension in Infants and Children. Antimicrob Agents Chemother. 1991;35(10):2042-2045.

3. Game, MD, Sakarkar DM, Gabhane KB, et al. Validated Spectrophotometric Methods for the Determination of Cefuroxime Axetil in Bulk Drug and tablets. International Journal of Chem Tech Research. 2010;2(2):1259-1262.
4. Amir SB, Hossain MA, Mazid MA. Development and Validation of UV Spectrophotometric Method for the Determination of Cefuroxime Axetil in Bulk and Pharmaceutical Formulation. Journal of Scientific Research. 2014;6(1):133-141.

5. Chaudhari SV, Ashwini K, Anuradha A, et al. Simultaneous UV Spectrophotometric method for the estimation of Cefuroxime Axetil and Probenecid From Solid Dosage Forms. Indian J Pharm Sci. 2006;68(1):59-63.

6. Ranjane PN, Gandhi SV, Kadukar SS, et al. HPTLC Determination of Cefuroxime Axetil and Ornidazole in Combined Tablet Dosage Form. $J$ Chromatogr Sci. 2010;48(1):26-28.

7. Shah NJ, SK Shah, VF Patel, et al. Development and validation of a HPLC method for the estimation of cefuroxime axetil. Indian Journal of Pharmaceutical sciences. 2007;69(1):140-142.

8. Sireesha KR, Deepali VM, Kadam SS, et al. Development and Validation of a HPTLC Method for the Simultaneous estimation of Cefuroxime Axetil and Probenecid. Indian J Pharm. 2004;66:278-282.

9. Bulitta JB, Landersdorfer CB, Kinzig M, et al. New Semiphysiological Absorption Model to Assess The Pharmacodynamic Profile of Cefuroxime Axetil Using Nonparametric and Parametric Population Pharmacokinetics. Antimicrob Agents Chemother. 2009;53(8):3462-3471.

10. Ingule P, Dalvi SD, Deepali D, et al. Simultaneous determination of cefuroxime axetil and potassium development is pharmaceutical dosage form by RP-HPLC. IJPPS. 2013;5(4):179-181.

11. Sengar Mahima R, Santosh V Gandhi, Upasana P Patil, et al. Reverse High Performance Liquid Chromatographic Method for Simultaneous Determination of Cefuroxime Axetil and Potassium Clavulanate in Tablet Dosage form. International Journal of Chem Tech Research. 2009;1(4):1105-1108.

12. Ivana I, Lijljana Z, Mira Z. A stability indicating assay method for cefuroxime axetil and its application to analysis of tablets exposed to accelerated stability test conditions. J Chromatogr A. 2006;1119(1-2):209-215.

13. Santosh Kumar P. A Validated HPLC method for the estimation of cefuroxime axetil. Research Journal of pharmaceutical biological and chemical sciences. 2012;3(3):223-228.

14. Garbacki P, Teżyk A, Zalewski P, et al. Assay of Diastereoisomers of Cefeuroxime axetil in amorphous and crystalline forms using UHPLC-DAD. Chromatographia. 2014;77(21-22):1489-1495.

15. Raj KA, Divya Y, Deepthi Y, et al. Determination of Cefixime Trihydroate and Cefuroxime axetil in bulk drug and pharmakeutical dosage forms by HPLC. International Journal of chemTech Research. 2010;2(1):334-336.

16. Pavankumar K, Jagadeeswaran M, Caroline G, et al. Development and Validation of Cefuroxime Axetil and lts associated interaction study with ariti-oxidants RP-HPLC. IAJPR. 2013;3(7):5062-5070.

17. Yuqian Du, Yinglei Z, Zhonggui He, et al. Development and evaluation of taste-masked dry suspension of cefuroxime axetil for enhancement of oral bioavailability. Asian J Pharma Sci. 2013;8(5):287-294.

18. Sonia K. Method development and validation of RP-HPLC for The determination of related impurities of Cefuroxime axetil in bulk and in pharmaceutical formulation. International journal of medicinal chemistry \& analysis. 2013;3(2):70-74.

19. USP30. United States Pharmacopeia. Rockville MD, USA. The United States Pharmacopeial Convention. Asian Edition. 2007. p. 1683-1685.

20. ICH. Draft guideline on validation of analytical procedures for pharmaceutical. Availability. International. 1994;59:40.

21. Kazakevich Y, Lobrutto R. HPLC for pharmaceutical scientists. USA: John Wiley \& sons Inc.; 2007. p. 7-11, 335, 360, 492, 358, 377, 747, 481 . 